\title{
Implementation of the Problem Based Learning Models to Improve Critical Thinking Skills in PKn
}

\section{Eni Kusniati}

Universitas Sebelas Maret

Kusniatieni01@gmail.com

\section{Article History}

received 30/4/2021

\begin{abstract}
Elementary school level output is expected to have critical thinking skills which is one of the characteristics of 21st century learning. This critical thinking skills education has become a demand in every lesson including Citizenship Education (PKn). Civics has an important role for human life to study relationships between humans in a multicultural environment. This study aims to improve the critical thinking skills of fourth grade elementary school students in Civics learning using the Problem Based Learning (PBL) model. This research is a Classroom Action Research (CAR) which consists of two cycles with three meetings in each cycle. The stages in each cycle consist of planning, implementation, observation, and reflection. Pre-test and posttest are carried out at each meeting to monitor the progress of students. Completeness of students after completing the post test cycle I was $40.91 \%$ and cycle II was $86.96 \%$. These results indicate that the Problem Based Learning (PBL) model can improve students' critical thinking skills in Civics learning class IV at SDN 1 Tersobo

Keywords: Critical Thinking, Problem Based Learning Model, Civics
\end{abstract}

\begin{abstract}
Abstrak
Output level Sekolah Dasar diharapkan memiliki keterampilan berpikir kritis yang merupakan salah satu ciri pembelajaran abad 21. Pendidikan keterampilan berpikir kritis ini telah menjadi sebuah tuntutan pada setiap pemelajaran termasuk Pendidikan Kwarganegaraan (PKn). PKn memiliki peran penting bagi kehidupan manusia untuk mempelajari hubungan antar manusia dalam lingkungan yang multikultural. Penelitian ini bertujuan meningkatkan keterampilan berpikir kritis peserta didik kelas IV sekolah dasar pada pembelajaran PKn menggunakan model Problem Based Learning (PBL). Penelitian ini merupakan Penelitian Tindakan Kelas (PTK) yang terdiri dari dua siklus dengan tiga pertemuan pada setiap siklusnya. Tahapan pada setiap siklusnya terdiri dari perencanaan, pelaksanaan, observasi, dan refleksi. Pre test dan post test dilakukan pada setiap pertemuan untuk memantau perkembangan peserta didik. Ketuntasan peserta didik setelah menyelesaikan post test siklus I sebanyak $40,91 \%$ dan siklus II sebanyak 86,96\%. Hasil tersebut menunjukkan model Problem Based Learning (PBL) dapat meningkatkan keterampilan berpikir kritis peserta didik pada pembelajaran PKn kelas IV SDN 1 Tersobo.
\end{abstract}

Kata kunci: Berpikir Kritis, Model Problem Based Learning, PKn 


\section{PENDAHULUAN}

Kehidupan abad ke-21 memiliki tanda seperti adanya perubahan IImu Pengetahuan dan Teknologi yang berkembang pesat. Sumber daya manusia dituntut memiliki kualitas keterampilan untuk menghadapi tantangan abad 21. Peserta didik merupakan salah satu sumber daya manusia yang harus memiliki keterampilan berpikir kritis. Cara berpikir, bertindak, dan pengambilan keputusan merupakan beberapa inovasi yang diperlukan. Pembelajaran memiliki beberapa kompetensi yaitu critical thinking, communication, collaboration, dan creativity. Keterampilan yang dimiliki oleh seseorang saat proses pengambilan keputusan dari berbagai sisi dan sudut pandang secara logis merupakan suatu keterampilan berpikir kritis. Menurut Ennis dalam Susanto (2013) keterampilan berpikir kritis memiliki beberapa indikator yaitu: memberikan suatu penjelasan yang sederhana, membangun suatu keterampilan yang mendasar, dapat menyimpulkan, memberikan suatu penjelasan berlanjut dan mengatur suatu strategi serta teknik. Keterampilan berpikir kritis PKn dalam memecahkan suatu permasalahan perlu adanya keaktifan dari peserta didik. Peserta didik dituntut mampu berpikir secara reflektif untuk memutuskan dan bertindak terhadap hal yang akan ditentukan maupun dilakukan sehingga perlu adanya suatu pertimbangan agar tidak salah dalam menentukan suatu keputusan dan tindakan. Hal tersebut sangat berkaitan dengan hubungan antar kehidupan manusia pada lingkungan multikultural. Pendidikan Kewarganegaraan sesuai PP Nomor 32 Tahun 2013 pasal 77 ayat 1 bermaksud membentuk peserta didik memiliki rasa kebangsaan dalam konteks Pancasila, kesadaran UUD 1945, kesesuaian kebhinekaan dan jiwa semangat NKRI, serta fokus pembentukan diri atas segala keragaman agama, sosiokultural, usia, bahasa, sosio-kultural, dan suku bangsa. Akan tetapi, menurut penelitian yang dilakukan oleh $\mathrm{R}$. Mustamiroh pembelajaran yang dilakukan setiap guru belum mampu melatih berpikir kritis sehingga Indonesia masih berkategori rendah dibandingkan beberapa negara lainnya. Sesuai hasil observasi ketika berlangsung praktik pengalaman lapangan tanggal 10 Januari hingga 22 Februari 2021 serta hasil wawancara tanggal 18 Januari 2021 dengan peserta didik kelas IV SD Negeri 1 Tersobo diperoleh bahwa masih rendahnya keterampilan berpikir kritis yang dimiliki. Keterampilan berpikir kritis dari hasil prantindakan tanggal 20 Januari 2021 bahwa hanya ada 2 dari 24 jumlah peserta didik di kelas atau sebanyak 8,34 \% yang dapat menggunakan keterampilan berpikir kritisnya. Sedangkan 91,66 \% atau sebanyak 22 peserta didik dari jumlah 24 belum dapat menggunakan keterampilan berpikir kritisnya.

Hal tersebut menjelaskan adanya fakta masih tergolong rendahnya keterampilan berpikir kritis yang dimiliki oleh peserta didik. Fakta terkait rendahnya keterampilan berpikir kritis harus ditangani segera. Penelitian oleh Zatmiko menggunakan model pembelajaran bermasis masalah mampu meningkatkan keterampilan peserta didik dalam berpikir kritis. Oleh karena itu, peneliti menggunakan pembelajaran inovatif berbasis masalah yaitu model Problem Based Leraning untuk meningkatkan keterampilan berpikir kritis PKn peserta didik. Sesuai sintaks model Problem Based Leraning oleh Shoimin (2016: 130) bahwa PBL bercirikan adanya permasalahan untuk dipecahkan oleh peserta didik dengan keterampilan berpikir kritis yang dimilikinya. Melatih serta mengembangkan kemampuan dalam menyelesaikan suatu masalah yang ada pada model PBL guna merangsang keterampilan dalam berpikir kritis menempatkan keaktifan peserta didik.

Berdasarkan pemaparan tersebut, peneliti bertujuan meningkatkan keterampilan peserta didik kelas IV SDN 1 Tersobo dalam berpikir kritis dengan menerapkan model PBL. Manfaat dengan menerapkan ini ialah peserta didik terlatih memberikan gagasan maupun ide kreatif serta pemecahan masalah yang dijumpai dalam kehidupan kesehariannya. yang ditemuinya didalam kehidupan sehari-hari. Terdapatnya peningkatan keterampilan dalam berpikir kritis pembelajaran PKn, 
menjadikan penelitian ini relevan guna mengembangkan pembelajaran dengan model lain dalam meningkatkan keterampilan berpikir kritis pembelajaran PKn.

\section{METODE}

Jenis penelitian ini yakni PTK dengan dua siklus dan subjek penelitian yakni peserta didik SDN 1 Tersobo kelas IV tahun ajaran 2020/2021 sejumlah 24 anak. Teknik yang digunakan dalam pengumpulan data yaitu observasi, wawancara, tes serta dokumentasi. Uji validitaas data menggunakan triangulasi teknik serta triangulasi sumber dengan tekniik analisis data model analisis interaktif Miles-Huberman.

Penggolongan keterampilan berpikir kritis pembelajaran PKn modifikasi Sukardjo adalah sebagai berikut.

Tabel 1. Penggolongan dan Konversi Skor Penilaian Keterampilan Berpikir Kritis

\begin{tabular}{cccc}
\hline Interval Skor & & Kategori & Keterangan \\
\hline $\mathrm{X}>\mathrm{M}_{\mathrm{i}}+1,8 . \mathrm{SB}_{\mathrm{i}}$ & $\mathrm{X}>12$ & Sangat Tinggi & Terampil \\
$\mathrm{Mi}+0,6 . \mathrm{SB}_{\mathrm{i}}<\mathrm{X} \leq \mathrm{Mi}+1,8$. & $9<\mathrm{X} \leq$ & Tinggi & Terampil \\
$\mathrm{Mi}-0,6 \mathrm{SBi}<\mathrm{X} \leq \mathrm{Mi}+0,6 \mathrm{Sbi}$ & $6<\mathrm{X} \leq 9$ & Rendah & Tidak \\
$\mathrm{X} \leq \mathrm{Mi}-0,6 \mathrm{Sbi}$ & $\mathrm{X} \leq 6$ & Sangat & Terampil \\
& & Rendah & Terampil \\
\hline
\end{tabular}

Keterangan

$\mathrm{X} \quad=$ Rerata skor

$\mathrm{M}_{\mathrm{i}} \quad=$ Mean ideal, $\mathrm{M}_{\mathrm{i}}=1 / 2$ (skor maksimal + skor minimal)

$\mathrm{SB}_{\mathrm{i}} \quad=$ Simpangan baku ideal

Pencapaian penelitian berpatokan predikat sangat tinggi dan tinggi, sehingga jika peserta didik memenuhi kategori tersebut maka dapat dikatakan terampil berpikir kritis pembelajaran PKn. Target penelitian ini yaitu $80 \%$ secara klasikal disertai predikat minimal "tinggi" dari soal berindikator keterampilan berpikir kritis.

\section{HASIL DAN PEMBAHASAN}

Hasil serta pembahasan dari penelitian dipaparkan dengan tiga penyajian terkait data perkembangan keterampilan peserta didik yaitu berpikir kritis. Data tersebut yaitu: pratindakan, siklus 1 , dan siklus 2 .

\subsection{Keterampilan Berpikir Kritis pada Pembelajaran PKn Pratindakan}

Model pembelajaran Problem Based Learning sebelum diterapkan diperoleh data yang menunjukkan keterampilan berpikir kritis peserta didik termasuk golongan rendah. Data pratindakan disajikan pada gambar 1 berikut ini. 


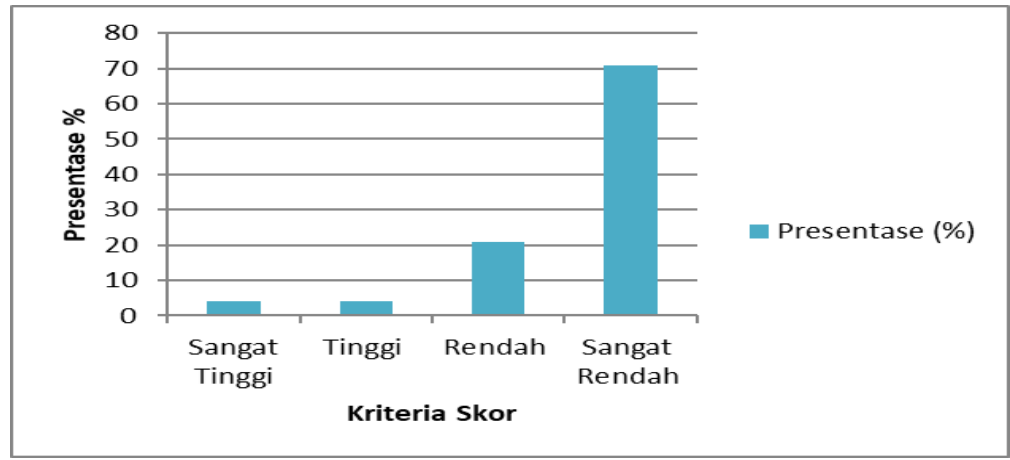

\section{Gambar 1. Hasil Keterampilan Berpikir Kritis pada Pembelajaran PKn Pratindakan}

Gambar 1 menjelaskan mengenai data perolehan keterampilan berpikir kritis pembelajran PKn ketika belum menerapkan model Problem Based Learning adalah tergolong rendah dengan predikat terampil sebanyak 8,34 \% meliputi predikat tinggi sebanyak $4,17 \%$ dan predikat yang sangat tinggi sebanyak $4,17 \%$. Sedangkan perolehan peserta didik yang tidak terampil sejumlah $91,7 \%$ meliputi predikat rendah sebanyak 20,73 \% sedangkan predikat yang sangat rendah sebanyak 70,83 \%. Keterampilan berpikir kritis yang rendah sesuai dengan penelitian yang dilakukan Abdurrahman bahwa hasil dari survey PISA serta TIMSS yang terakhir yakni tahun 2015 memperlihatkan Indonesia memperoleh rangking yang dramatis.

\subsection{Keterampilan Berpikir Kritis pada Pembelajaran PKn Siklus 1}

Perolehan hasil penelitian setelah mengaplikasikan model Problem Based Learning yakni keterampilan peserta didik dalam berpikir kritis meningkat lebih baik pada siklus I. Data penyajian siklus I ditunjukkan oleh Gamba 2 berikut ini.

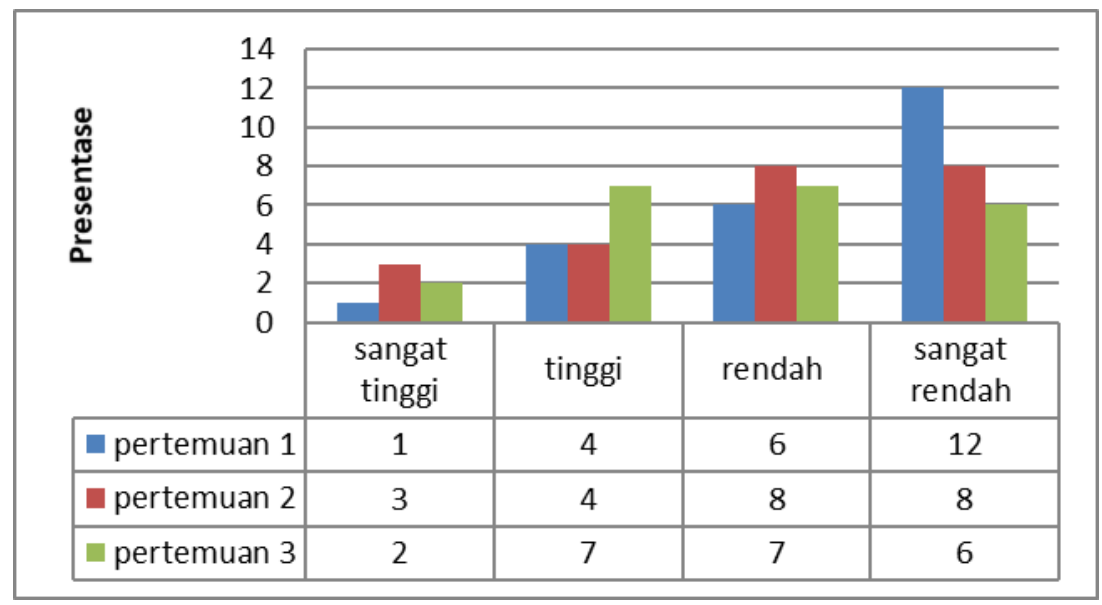

Gambar 2. Hasil Keterampilan Berpikir Kritis pada Pembelajaran PKn Siklus 1

Gambar 2 menjelaskan mengenai perolehan data keterampilan peserta didik dalam berpikir kritis pada pembelajaran PKn yang mengalami peningkatan setiap pertemuannya. Perolehan pada pertemuan 1 yaitu sejumlah $21,74 \%$ tergolong terampil dengan predikat sangat tinggi sebanyak 4,35 \% dan tinggi sebanyak $17,39 \%$. Sedangkan peserta didik yang tidak terampil sebanyak 78,26 \% dengan berpredikat rendah sebanyak 26,09 \% serta berpredikat sangat rendah sebanyak 52,17 \%. Perolehan pertemuan yang ke-2 pada peserta didik yaitu berpresentase terampil sebanyak $30,43 \%$ dengan predikat yang sangat tinggi sebanyak $13,03 \%$ dan tinggi sebanyak 17,39 \%. Sedangkan, yang tidak terampil sebanyak 69,57 \% dengan 
predikat rendah sebanyak $34,78 \%$ dan berpredikat sangat rendah sebanyak $34,78 \%$. Perolehan data pada pertemuan 3 terkait keterampilan peserta didik dalam berpikir kritis sebanyak 40,91\% dikatakan terampil dengan presentase sangat tinggi sebanyak $09,09 \%$ serta berpredikat tinggi sebanyak 31,82 \%, sedangkan perolehan peserta didik yang tidak terampil sebanyak $59,09 \%$ dengan predikat rendah sebanyak $31,82 \%$ dan persentase berpredikat sangat rendah sebanyak $27,27 \%$. Akan tetapi, peningkatan hasil dari persentase di siklus I belum dikatakan mencapai target yang diharapkan yaitu sejumlah $80 \%$. Oleh karena itu, penelitian dilanjutkan pada siklus yang ke II untuk memperbaiki siklus I.

\subsection{Keterampilan Berpikir Kritis pada Pembelajaran PKn Siklus II}

Penelitian dengan mengaplikasikan model pembelajaran Problem Based Learning diperoleh hasil bahwa keterampilan peserta didik dalam berpikir kritis PKn telah mengalami peningkatan hasil dari pratindakan serta siklus I. Penyajian hasil pada siklus II ditampilkan paa Gambar 3 berikut ini.

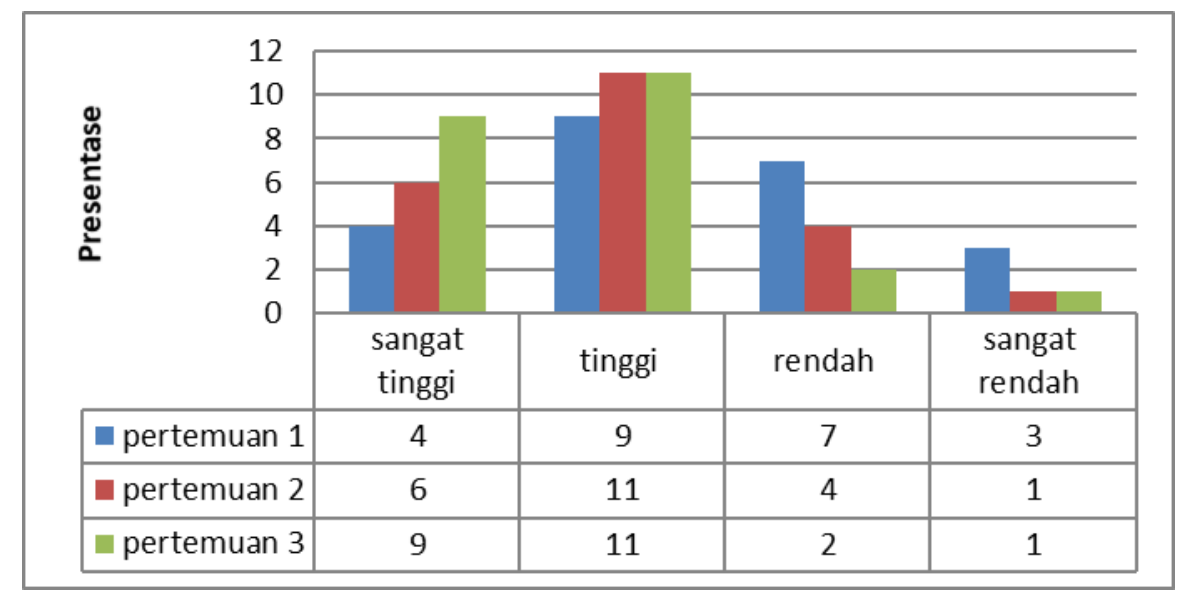

Gambar 3. Hasil Keterampilan Berpikir Kritis pada Pembelajaran PKn Siklus II

Gambar 3 menjelaskan perolehan hasil keterampilan berpikir kritis PKn yang mengalami peningkatan pada setiap pertemuannya. Perolehan pada pertemuan 1 yaitu sebanyak $56,53 \%$ peserta didik terampil dengan $17,39 \%$ berpredikat sangat tinggi dan 39,17\% berpredikat tinggi, sedangkan peserta didik dengan persentase tidak terampil sebanyak 43,48 \% dengan 30,43 \% berpredikat rendah dan 13,04\% berpredikat sangat rendah. Perolehan hasil pertemuan 2 yaitu sebanyak 77,27 \% dikatakan terampil dengan $27,27 \%$ berpredikat sangat tinggi dan 0,5\% berpredikat tinggi, sedangkan peserta didik dengan persentase tidak terampil sebanyak 22,73\% dengan 18,18 \% berpredikat rendah dan 04,55\% berpredikat sangat rendah. Perolehan pertemuan 3 yaitu sebanyak $86,96 \%$ terampil dengan 39,13\% berpredikat sangat tinggi dan $47,83 \%$ berpredikat tinggi, sedangkan persentase tidak terampil pada peserta didik sebanyak $13,04 \%$ dengan 08,07 \% berpredikat rendah dan 04,35 $\%$ berpredikat sangat rendah. Perolehan pada pertemuan 3 siklus yang ke-2 telah mencapai target indicator kerja dalam penelitian ini. Oleh karena itu, penelitian terkait penerapan model Problem Based Learning dalam pembelajaran menyatakan berhasil serta dapat menaikkan keterampilan berpikir kritis.

Hasil tes dari tindakan yang telah terlaksana membuktikan kebenaran dari hasil penelitian ini menunjukkan kenaikan. Hal tersebut telah mampu membuktikan bahwa penerapan model Problem Based Learning meningkatkan keterampilan berpikir kritis. 
Hal tersebut karena model Problem Based Learning merupakan pengaplikasian teori konstruktivisme karena peserta didik membangun pemikirannya sendiri dari pengalaman-pengalaman, menerapkan pengetahuan, harus mampu bekerja dengan memecahkan masalah dengan ide-idenya sendiri sehingga pemahaman lebih baik lagi. Penelitian oleh Zatmiko dan Suntoro (2017) menunjukkan bahwa model Problem Based Learning merupakan model pembelajaran yang efektif dalam melatih berpikir kritis. Hail pratindakan hanya sebanyak $8,34 \%$ yang kemudian diatasi menggunakan model Problem Based Learning untuk meningkatkan keterampilan berpikir kritis. Peningkatan pada setiap pertemuan membuktikan ketercapaian keterampilan peserta didik dalam berpikir kritis. Keterampilan berpikir kritis melalui penerapan model Problem Based Learning yang telah meningkat sejalan dengan penelitian Sukaptiyah (2018) bahwa model pembelajaran Problem Based Learning berhasil meningkatkan keterampilan berpikir kritis peserta didik di SDN 1 Mongkrong.

\section{SIMPULAN}

Berdasarkan hasil uraian dari penelitian dapat disimpulkan bahwa penerapan model Problem Based Learning berhasil meningkatkan keterampilan berpikir kritis pada pembelajaran PKn kelas IV SDN 1 Tersobo tahun ajaran 2020/2021. Hal tersebut dibuktikan dari perolehan hasil ketrampilan berpikir kritis pratindakan sebanyak 8,34\% meningkat hasilnya menjadi 86,96 \% di akhir pertemuannya. Hasil penelitian sebagai implikasi teoritis menambah ilmu serta wawasan yang dapat digunakan sebagai sumber yang relevansi penelitian sejenis. Implikasi praktis dalam penelitian terkait peningkatan keterampilan berpikir kritis PKn setelah menerapkan model Problem Based Learning yaitu keefektifan dan keefisiensian model ini untuk mengatasi masalah sejenis dapat diterapkan dengan baik pada permasalahan yang lain.

\section{DAFTAR PUSTAKA}

Agoestanto, K. U. (2017). Implementasi Model Pembelajaran PBL terhadap Kemampuan Berfikir Kritis dan Kedisiplinan Peserta didik. journal.unnes.ac.id, 537.

Arends, R. I. (2013). Belajar untuk Mengajar (Learning to Teach). Jakarta : Salemba Humanika

A T A H Regina Yuliani Suganda Stefanus Christian Relmasira 2018 Penerapan Model Pembelajaran Cooperative Integrated Reading Composition untuk Meningkatkan Keterampilan Menulis dan Berpikir Kritis Siswa Kelas III Sekolah Dasar J Didakt Dwija Indria 6(7) pp 8-15.

Haris, A. J. (2013). Evaluasi Pembelajaran. Yogyakarta: Multi Pressindo.

Huda, M. (2013). Model-model Pengajaran dan Pembelajaran. Yogyakarta: Pustaka Pelajar.

Ikman, H. M. (2016). Effect of Problem Based Learning (PBL) Models of Critical Thinking Ability Students on The Early Mathematics Ability. International Journal of Education and Research, 364.

K E Lestari 2014 Implementasi Brain-Based Learning untuk Meningkatkan Kemampuan Koneksi dan Kemampuan Berpikir Kritis serta Motivasi Belajar Siswa SMP J Pendidik Unsika 2(1) pp 36-46

Pandu, L. B. (2017). Penerapan Model Problem Based Learning untuk Meningkatkan Keaktifan dan Hasil Belajar Peserta didik pada Pelajaran Komputer. eprints.uny.ac.id, 74.

R Hidayah M Salimi and T S Susiani 2017 Critical Thinking Skill Konsep dan Indikator Penilaian J Taman Cendekia 1(2) pp 66-88

Rojana Phungsuk, C. V. (2017). Development of a problem-based learning model via a virtual learning environment. Kasetsart Journal of Social Sciences , 303.

Shoimin, A. (2016). 68 Model Pembelajaran Inovatif. Yogyakarta: Ar-Ruzz Media. 
Siswono, K.-L. d. (2018). Penelitian Tindakan Kelas. Bandung: PT Remaja Rosdakarya.

Soyomukti, N. (2013). Teori-teori Pendidikan. Yogyakarta: Ar-Ruzz Media.

Sugiyono. (2015). Metode Penelitian Pendidikan. Bandung: Alfabeta

Susanto, A. (2013). Teori Belajar \& Pembelajaran. Jakarta: Kencana Prenadamedia Group.

Y Gotoh 2016 Development of Critical Thinking with Metakognitive Regulation J 13 Int Conf Cogn Explor Learn Digit age ( CELDA 2016) pp 353-356 